\title{
HEPATOPROTECTIVE ACTIVITY OF STEM BARK OF BAUHINIA
}

\section{TOMENTOSA}

\author{
Parimal P. Katolkar ${ }^{1}$ and Nandakishore J. Duragkar ${ }^{2}$ \\ 1 Manoharbhai Patel Institute Of Pharmacy, Kudwa, Gondia 441614. MS, India 2 \\ Sharad Pawar College Of Pharmacy, Wanadongri, Hingna Road, Nagpur \\ 441110, (Ms) India \\ Corresponding author Email : p_k_7995@yahoo.co.in
}

\begin{abstract}
:
The main objective of the study is to evaluate hepatoprotective activity of ethanolic extract of bark of Bauhinia tomentosa (BTEE) against CCl4 induced hepatotoxicity using Albino wistar rats weighing $150-200 \mathrm{~g}$. Silymarin $(100 \mathrm{mg} / \mathrm{kg})$ orally was used as standard drug. Test groups received Ethanolic extract of bark of Bauhinia tomentosa (BTEE) in the doses of 200, 300 and $400 \mathrm{mg} / \mathrm{kg} /$ day orally along with $\mathrm{CCl} 4$ for 7 days. The hepatoprotective effect of BTEE was evaluated by assessment of biochemical parameters viz; Serum glutamate pyruvate transaminase (SGPT), serum glutamate oxaloacetate transaminase (SGOT), alkaline phosphatase (ALP), low density lipoproteins (LDL), high density lipoproteins (HDL), bilirubin, cholesterol and triglycerides were measured. Histopathological examination of the liver was also done. BTEE (300 mg/ $\mathrm{kg}$ and $300 \mathrm{mg} / \mathrm{kg}$ ) exhibited highly significant result in biochemical evaluation. Histopathological examination of the liver suggested hepatoprotective effect of the extract by decreasing the extent of centrilobular necrosis, fatty changes and congestion of sinusoids when compared to carbon tetrachloride group. BTEE showed significant dose dependent protection against carbon tetrachloride induced liver injury in rats.
\end{abstract}

\section{Keywords:}

Carbon tetrachloride (CC14), Bauhinia tomentosa ethanolic extract (BTEE), Biochemical parameters, histopathologcal studies, hepatoprotective.

\section{Introduction:}

Treatment options for common liver diseases such as drug induced hepatitis, fatty liver and chronic hepatitis are very few and only supportive. The effectiveness of agents available for the treatment of liver disease are inconsistent and have greater incidence of side-effects [1]. Bauhinia tomentosa (Fam. Fabaceae) commonly known as Kanchana is a medium-sized, deciduous tree, found throughout India. It contains aurones, catechol - tannins, elegiac 
acid, flavonoid, phenol, steroids, triterpenoids and proteins.[2] In ayurveda, it is used in the treatment of inflammation in liver, vermifuge, dysenteric affections, diuretic, snake bite and scorpion sting. [3] As Efficacious, safe and cost effective medical therapies for various liver ailments are lacking, natural sources like plants are required to be explored for protection against liver injuries produced by various harmful agents. The main objective of the present work was to screen the hepatoprotective activity of bark of Bauhinia tomentosa by inducing carbon tetrachloride in albino wistar rats.

\section{Material and Method:}

Animals Wistar albino rats of either sex weighing150-200 g were used in present studies. Animals were obtained from the Laboratory Animal Centre, Department of Pharmaceutical Sciences, Rashtrasant Tukadoji Maharaj

Nagpur University, Nagpur, India. The rats were grouped and housed in polyacrylic cages $(38 \times 23 \times 10 \mathrm{~cm})$ with not more than four animals per cage and maintained under standard laboratory conditions (temperature $25 \pm 2^{\circ} \mathrm{C}$ with dark/light cycle $12 / 12 \mathrm{~h}$ ). They were allowed free access to standard dry pellet diet (Hindustan Lever, Kolkata, India) and water. All experimental procedures were reviewed and approved by to the Committee for the Purpose of Control and Supervision on Experiments on Animal (CPCSEA) or Institutional Animal Ethical Committee (IAEC), Nagpur University, Nagpur, India. Plant material and Preparation of Extracts The bark of Bauhinia tomentosa was collected from the Satpura Botanical Garden, Nagpur. The above material was botanically identified and confirmed from the Department of Botany, RTM Nagpur University, Nagpur. The plant specimen was dried, its herbarium sheet was prepared and it was authenticated at Department of Botany, RTM Nagpur University, Nagpur. Specimen voucher no. 9303. Barks were cut in to small pieces, sun dried, pulverized in coarse powder $(500 \mathrm{~g})$ and charged in a Soxhlet apparatus and successively extracted with Petroleum ether and Ethanol. Chemicals Tween-80 (Merck), Carbon tetrachloride (Merck) and Silymarin 
(Sigma-Aldrich, USA) were used. Experimental design Albino wistar rats of either sex weighing 150-200g were divided into six groups, containing six animals each. Group I (Normal control) received distilled water $(1 \mathrm{ml} / \mathrm{kg} / \mathrm{d}$, orally) only. Group II (Negative Control) was given carbon tetrachloride (CCl4) 1 $\mathrm{ml} / \mathrm{kg} / \mathrm{d}$ dissolved in olive oil $(1: 1)$ orally[4]. Group III (Positive control) received Silymarin $(100 \mathrm{mg} / \mathrm{kg})$ orally along with CCl4 $(1 \mathrm{ml} / \mathrm{kg})$ [5]. Test groups (III-VI) received Ethanolic extract of stem bark of Bauhinia tomentosa (BTEE) in different doses with CCl4 $(1 \mathrm{ml} / \mathrm{kg})$ as follows: IV- BTEE $(200 \mathrm{mg} / \mathrm{kg})+\mathrm{CCl} 4$ $(1 \mathrm{ml} / \mathrm{kg})$. V- BTEE $(300 \mathrm{mg} / \mathrm{kg})+\mathrm{CCl} 4(1 \mathrm{ml} / \mathrm{kg})$ VI- BTEE $(400 \mathrm{mg} / \mathrm{kg})+\mathrm{CCl} 4$ $(1 \mathrm{ml} / \mathrm{kg})$. All the groups were given the above treatment daily for 7 days.

Assessment of hepatoprotective activity On 8th day the animals were sacrificed under ether anaesthesia and blood was collected by direct cardiac puncture. Liver was dissected out and $500 \mathrm{mg}$ of liver tissue was taken for determination of the levels of antioxidant Enzymes. Rest of the liver was kept in 10\% formalin for histopathological examination. Determination of serum biochemical parameters $[6,7,8]$ The collected blood was centrifuged at $5000 \mathrm{rpm}$ for 10 minutes and serum was separated. Serum was analyzed for biochemical parameters like Serum glutamate pyruvate transaminase (SGPT), serum glutamate oxaloacetate transaminase (SGOT), alkaline phosphatase (ALP), low density lipoproteins (LDL), high density lipoproteins (HDL), bilirubin, cholesterol and triglycerides were measured. Histopathological examination Liver tissue was fixed in $10 \%$ formalin, dehydrated in graded ethanol and embedded in paraffin wax. Sections were prepared and stained with hematoxylin and eosin. The slides thus prepared were observed for histopathological features under the microscope. Statistical Analysis The results were expressed as Mean \pm Standard Error of Mean (SEM). The groups were compared by one way analysis of variance (ANOVA) followed by post hoc "Dunnett"s Multiple comparison test" to analyze statistical significance. $p<$ 0.05 was considered to be significant. 


\section{Result and Discussion:}

Administration of $\mathrm{CCl} 4$ at a dose of $1.0 \mathrm{ml} / \mathrm{kg}$ (p.o.) showed significant rise $(\mathrm{P}<0.001)$ in level of SGOT, SGPT, ALP, LDL, bilirubin, cholesterol and triglycerides while significant decrease $(\mathrm{p}<0.001)$ in the level of HDL. Silymarin significantly $(\mathrm{P}<0.001)$ changed these levels near to normal. A significant $(\mathrm{P}<0.01)$ decrease in the level of SGOT, SGPT, ALP, LDL, bilirubin, cholesterol and triglycerides while significant increase $(\mathrm{p}<0.001)$ in the level of HDL were observed. Animals were treated with different doses $(200 \mathrm{mg} / \mathrm{kg}, 300 \mathrm{mg} / \mathrm{kg}$ and $400 \mathrm{mg} / \mathrm{kg}$ ) of ethanolic extracts and they showed dose dependant activity. At the dose of $400 \mathrm{mg} / \mathrm{kg}$ methanolic extract showed comparable activity with the standard drug silymarin. (Table 1) Histopathological studies showed CC14 produced extensive vascular degenerative changes and centrilobular necrosis in hepatocytes. Treatment with silymarin, acetonic and methanolic extracts produced mild degenerative changes and absence of centrilobular necrosis when compared with control. All these results indicate a hepatoprotective potential of extracts of B. tomentosa. Methanolic and acetonic extracts showed a dose dependent activity which was confirmed by histopathological examination. (Fig 1) DISCUSSION Elevated levels of serum enzymes like SGOT, SGPT are indicative of cellular leakage and loss of functional integrity of cell membrane in liver. Alkaline phosphatase concentration is related to the functioning of hepatocytes. High level of alkaline phosphatase in the blood serum is related to the increased synthesis of it by cells lining bile canaliculi usually in response to are increased while level of HDL decreased due to cholestasis and increased biliary pressure. Serum bilirubin is one of the most sensitive tests employed in the diagnosis of hepatic diseases. Hyperbilirubinemia was observed due to excessive heme destruction and blockage of biliary tract. Levels of triglycerides, LDL, and cholestrol in blood impairment in cholesterol and lipoprotein metabolism. 


\section{Conclusion:}

From the results, it can be concluded that extracts of B. tomentosa bark have hepatoprotective activity against the hepatotoxic substances like CC14 and its activity is comparable with standard drug silymarin. Ethanolic extracts contains same phytoconstituents like flavonoids, tannins and triterpanoids that may be responsible for hepatoprotective activity. So in future, attempt should be made to isolate the active constituents from the extracts and screen their hepatoprotective activity which may reduce dose and give potent hepatoprotective activity.

\section{Reference:}

Luper S. A review of plants used in the treatment of liver disease: partI. Altern Med Rev. 1998, 3(6):410-421.

Anonymous. The Ayurvedic Pharmacopoeia of India, Part I, Vol.1 Government of India, Ministry of Health and Family Welfare, Depatment of Ayush ,New Delhi, India, p.73-74

Khare CP. Bauhinia tomentosa. Indian medicinal plants. Springer.2007: p.8687.

Vogel HG.Liver function. Drug discovery and evaluation. 2nd edition.SpringerVerlag Berlin Heidelberg 2002.p.943

Praveen TK, Dharmaraj S, Bajaj J et.al. Hepatoprotective activity of petroleum ether, diethyl ether, and methanol extract of Scoparia dulcis L. against CCl4 induced injury in mice. Indian J pharmacol. 2009;41(3):110-114

Reitman S, Frankel S. A colorimetric methods for the determination of serum levels of glutamic oxaloacetic acid and pyruvic acid transaminases. Am. J. Clin. Pathol. 1957. 10:394-399 
Walton H. Marsh, Benjamin Fingerhut, Elaine Kirsch, Adaption of alkaline phosphatase method for automatic colorimetric analysis. Clinical Chemistry.1959; 5: 119-126

Jendrassik-Gróf method on photometric systems for in vitro determination of direct and total bilirubin. Biochem Zeitschrift.1938;297:82-9 .

Table 1: Biochemical parameters of different groups for $\mathrm{CCl}_{4}$ induced hepatotoxicity

\begin{tabular}{|c|c|c|c|c|c|c|c|c|}
\hline Groups & $\begin{array}{r}\text { SGPT } \\
(\mathrm{U} / \mathrm{L})\end{array}$ & $\begin{array}{c}\text { SGOT } \\
(\mathbf{U} / \mathbf{L})\end{array}$ & $\begin{array}{l}\text { ALP } \\
(\mathbf{U} / \mathbf{L})\end{array}$ & $\begin{array}{c}\text { LDL } \\
(\% \mathrm{mg})\end{array}$ & $\begin{array}{c}\text { HDL } \\
\text { (\%mg) }\end{array}$ & $\begin{array}{c}\text { Bilirubin } \\
\text { (\% mg) }\end{array}$ & $\begin{array}{c}\text { Choleste- } \\
\text { rol } \\
(\% \mathrm{mg})\end{array}$ & $\begin{array}{c}\text { Triglyceri- } \\
\text { des } \\
(\% \mathrm{mg})\end{array}$ \\
\hline I & $\begin{array}{l}49.93 \pm \\
1.5 * * *\end{array}$ & $\begin{array}{l}31.38 \pm \\
1.93 * * *\end{array}$ & $\begin{array}{l}152.7 \pm \\
2.94 * * *\end{array}$ & $\begin{array}{l}13.17 \pm \\
1.58 * * *\end{array}$ & $\begin{array}{l}63.38 \pm \\
2.03 * * *\end{array}$ & $\begin{array}{l}108.3 \pm \\
2.08 * * *\end{array}$ & $\begin{array}{l}0.76 \pm \\
0.016^{* *}\end{array}$ & $\begin{array}{l}92.79 \pm \\
1.95 * * *\end{array}$ \\
\hline II & $\begin{array}{l}94.73 \pm \\
1.6 * * *\end{array}$ & $\begin{array}{l}71.89 \pm \\
2.20 * * *\end{array}$ & $\begin{array}{l}320.7 \pm \\
1.04 * * *\end{array}$ & $\begin{array}{l}64.30 \pm \\
1.66 * * *\end{array}$ & $\begin{array}{l}17.31 \pm \\
2.05^{* * *}\end{array}$ & $\begin{array}{l}229.3 \pm \\
1.97 * * *\end{array}$ & $\begin{array}{l}1.02 \pm \\
0.01 * *\end{array}$ & $\begin{array}{l}215.5 \pm \\
2.15 * * *\end{array}$ \\
\hline III & $\begin{array}{l}61.62 \pm \\
1.3 * * *\end{array}$ & $\begin{array}{l}40.60 \pm \\
2.39 * * *\end{array}$ & $\begin{array}{l}195.3 \pm \\
2.45 * * *\end{array}$ & $\begin{array}{l}16.02 \pm \\
1.61 * * *\end{array}$ & $\begin{array}{l}45.52 \pm \\
1.88 * * *\end{array}$ & $\begin{array}{l}174.6 \pm \\
2.17 * * *\end{array}$ & $\begin{array}{l}0.67 \pm \\
0.01 * *\end{array}$ & $\begin{array}{l}140.0 \pm \\
1.83 * * *\end{array}$ \\
\hline IV & $\begin{array}{l}81.28 \pm \\
1.32 * *\end{array}$ & $\begin{array}{c}59.28 \pm \\
2.02 *\end{array}$ & $\begin{array}{c}260.82 \pm \\
1.276^{*}\end{array}$ & $\begin{array}{c}35.17 \pm \\
0.903 * *\end{array}$ & $\begin{array}{c}31.25 \pm \\
1.70 *\end{array}$ & $\begin{array}{c}190.26 \pm \\
1.28 * *\end{array}$ & $\begin{array}{l}0.97 \pm \\
0.005\end{array}$ & $\begin{array}{l}168.6 \pm \\
1.94 * *\end{array}$ \\
\hline $\mathrm{V}$ & $\begin{array}{l}75.56 \pm \\
1.51 * *\end{array}$ & $\begin{array}{c}54.58 \pm \\
2.39 *\end{array}$ & $\begin{array}{c}250.28 \pm \\
1.89 * *\end{array}$ & $\begin{array}{l}30.25 \pm \\
0.95^{* *}\end{array}$ & $\begin{array}{l}32.30 \pm \\
1.64 * *\end{array}$ & $\begin{array}{c}185.56 \pm \\
1.82 * *\end{array}$ & $\begin{array}{l}0.95 \pm \\
0.007\end{array}$ & $\begin{array}{l}165.5 \pm \\
1.82 * *\end{array}$ \\
\hline VI & $\begin{array}{l}70.29 \pm \\
1.32 * *\end{array}$ & $\begin{array}{l}50.56 \pm \\
2.45^{* *}\end{array}$ & $\begin{array}{c}240.54 \pm \\
1.86^{* *}\end{array}$ & $\begin{array}{l}25.28 \pm \\
0.94 * *\end{array}$ & $\begin{array}{l}35.67 \pm \\
1.58 * *\end{array}$ & $\begin{array}{c}180.50 \pm \\
1.72 * *\end{array}$ & $\begin{array}{c}0.85 \pm \\
0.005^{*}\end{array}$ & $\begin{array}{l}160.3 \pm \\
1.68 * *\end{array}$ \\
\hline
\end{tabular}

Values are expressed as mean \pm SEM for six animals in each group.

* Level of significance $\mathrm{p}<0.05$

**Level of significance $\mathrm{p}<0.01$

*** Level of significance $p<0.001$ 


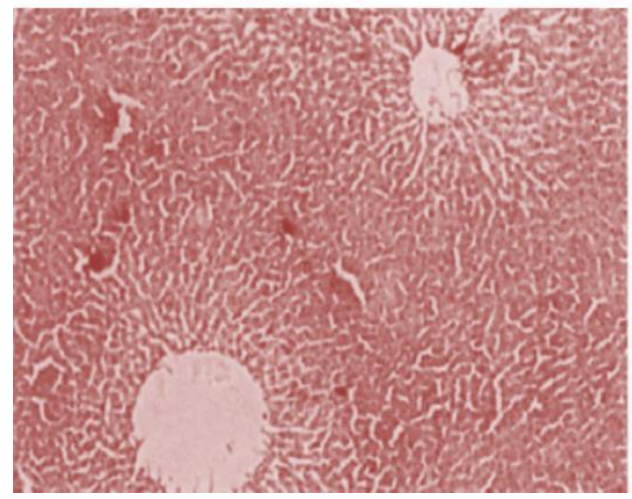

a) Normal liver Section showing prominent central vein \& normal hepatocytes \& sinusoids of liver

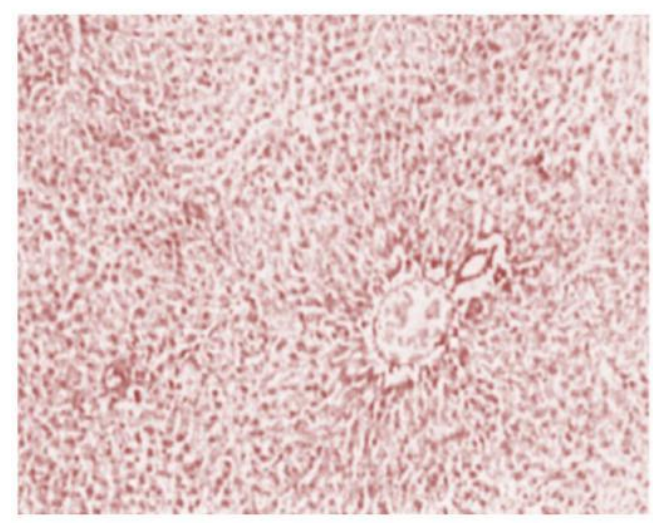

c) Silymarin treated liver showing almost normal liver architecture

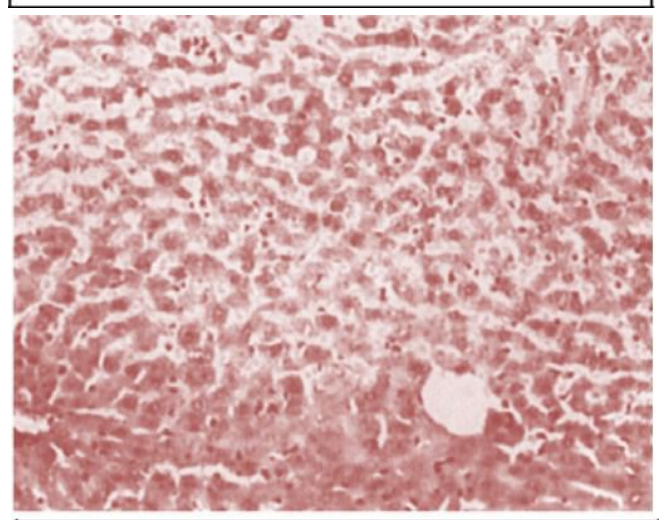

e) Methanolic extract $(300 \mathrm{mg} / \mathrm{kg})$ treated liver showing few areas of liver cell necrosis \& degeneration

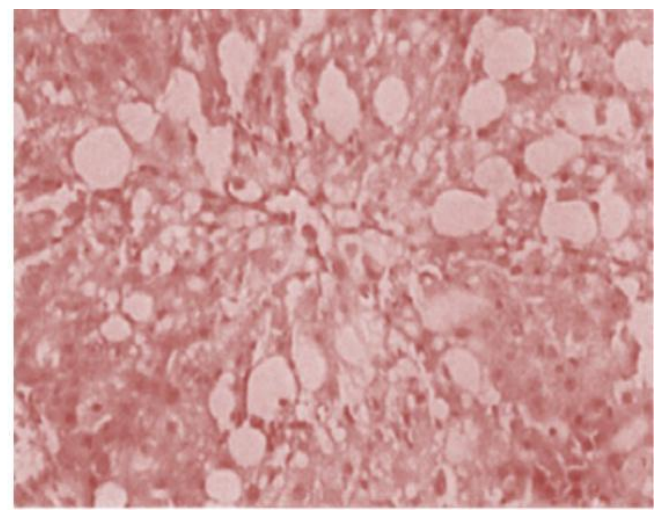

b) $\mathrm{CCl}_{4}$ treated liver showing focal areas of liver cell necrosis and degeneration and fatty changes

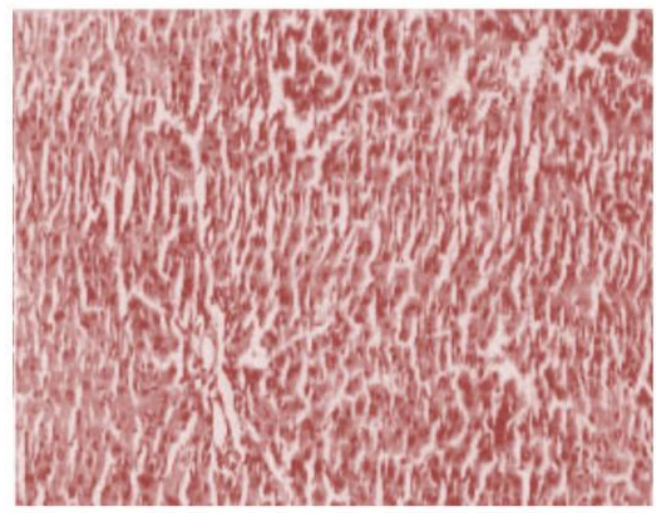

d) Methanolic extract $(200 \mathrm{mg} / \mathrm{kg})$ treated liver showing focal hepatocytes necrosis \& inflammation

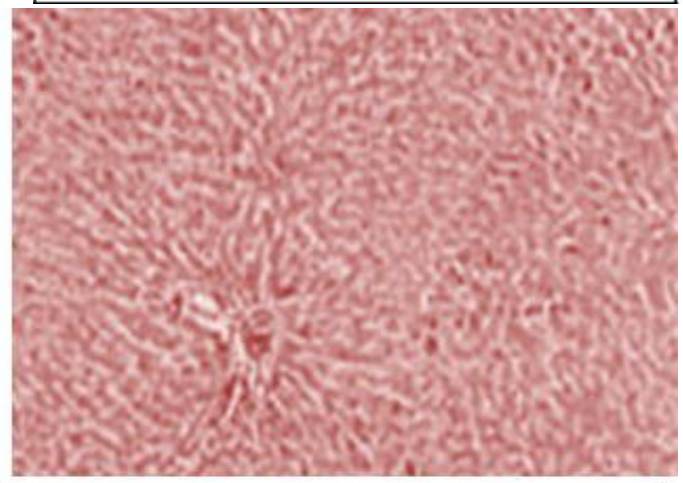

f) Methanolic extract $(400 \mathrm{mg} / \mathrm{kg})$ treated liver showing normal central vein and hepatocytes 
Fig 1: Effect of B. tomentosa bark extract on $\mathrm{CCl}_{4}$ induced liver damage

A Four Monthly Peer Reviewed Journal 